\title{
An instrumental analysis of oral monophthongs in Aceh Barat dialect of Acehnese
}

\author{
1Tanzir Masykar, ${ }^{1}$ Roni Agusmaniza, ${ }^{2}$ Nurul Taflihati Masykar, \\ ${ }^{3}$ Febri Nurrahmi* \\ ${ }^{1}$ Akademi Komunitas Negeri Aceh Barat, Indonesia \\ ${ }^{2}$ Aceh Learning Center, Banda Aceh, Indonesia \\ ${ }^{3}$ Department of Communication, Faculty of Social and Political Science, Syiah \\ Kuala University, Indonesia \\ *Corresponding Author \\ Email: febri.nurrahmi@unsyiah.ac.id
}

Received: $\quad$ Revised: Accepted: Published:

07 May $2020 \quad$ 28 July $2021 \quad$ 01 August $2021 \quad 31$ August 2021

\begin{abstract}
As among the ten most spoken languages, Acehnese inevitably has many varieties. Many previous studies on Acehnese have been heavily conducted on the northern varieties of Acehnese, leaving other Acehnese varieties unexplored. Pase dialect of Acehnese has been described to have oral and nasal monophthongs and diphthongs, but no studies on Aceh Barat dialect phonetic features of Acehnese have been made. Aceh Barat dialect has also been stigmatized as being rough and vulgar in the previous study. Thus, the current study aims to explore the instrumental analysis of Acehnese oral monophthongs by Aceh Barat speakers. Three male speakers (aged 35-50 years old) speaking only Acehnese as the local language participated in the current study. The ten Acehnese words used to target the ten phonemes were adapted from study. A total of 90 tokens of Acehnese oral vowels production were analyzed using PRAAT version 6.1.29. The oral monophthongs of the Aceh Barat dialect are generally similar to the previous study on the Pase dialect. Exception emerges for the vowel $/ \mathrm{A} /$ and $/ \mathrm{d} /$, which seems to be produced differently across the speakers. Both vowels appear to stretch further down the vowel space closer to the back vowels / $\mathrm{u} /$ and / $\mathrm{o} /$, respectively.
\end{abstract}

Keywords: Aceh Barat dialect; Acehnese oral vowels; Acehnese varieties

\section{INTRODUCTION}

With a total number of speakers reaching 3.5 million, Acehnese is among the ten most spoken local languages in Indonesia. To put it in perspective, the four most spoken languages in Indonesia have speakers of more than 5 million, while the rest of the ten most spoken local languages has speakers of less than 4 million. With such a vast number of speakers, regional varieties of Acehnese inevitably exist throughout the regions in Aceh province. Asyik (1987) suggested that Acehnese only has four major dialects, Banda Aceh, Pidie, Pase, and 
Meulaboh. However, Durie (1985) argued that Acehnese spoken in Greater Aceh (Banda Aceh in Asyik's) and Daya (Meulaboh in Asyik's) in the west coast of Aceh have greater varieties compared to those spoken in northern part of Aceh (Pidie and Pase dialects) which Durie (1985) described as more uniformed. In addition, an impression report by Durie (1985) also mentioned that with a distance of only a few kilometers in the western part of Aceh, one would find more variety in dialects compared to two hundred kilometers distance in the northern part of Aceh. Such variety is so distinct to the point that would be challenging for other Acehnese to understand. People in Banda Aceh, for example, were reported to have difficulties in grasping the Aceh Besar dialect despite it is the same language.

One way to record and document varieties of Acehnese dialect is by studying vowel sounds produced by Acehnese speakers. However, previous studies on Acehnese vowels have been exclusively focused on the northern dialects, such as Pillai and Yusuf (2012), Yusuf and Pillai (2013), and Yusuf and Pillai (2016), leaving the western dialects understudied. The earlier studies of Acehnese contextual grammar and its sounds by Asyik (1987) and Durie (1985) were also based on the northern dialects. In relation to this, Aziz (2015) argued that the western dialect of Aceh had been stigmatized as 'rough' and 'vulgar' while the northern dialects were regarded as 'refined' and standard.' He also mentioned that North and West Acehnese used different vowel equivalences in Indonesian loanwords and in some words, even substitute Indonesian vowels with the vowel /u/.

Thus, an acoustic study on vowels in the western part of Aceh would academically promote diversities in Acehnese dialects. It would also enrich the existing literature in the varieties of Acehnese vowel inventories. This study aims to identify and document oral vowels produced by the West Acehnese. Specifically, it would seek to acoustically map the monophthongs of Acehnese vowels into vowel space.

\section{Dialects in west coast of Aceh}

Researchers in previous studies have used the word "Standard Acehnese" to refer to the North dialects (Asyik, 1987; Sulaiman et al., 1977), while Durie (1985) referred to it as having most speakers and the most uniform variety. The use of "Standard Acehnese" by many researchers in Academic literature is misleading since no consensus has officially been made. Such designation only worsens the already stigmatized other dialects of Acehnese, such as West Aceh Dialect as reported by Aziz (2015) as 'rough' and 'vulgar.' What Asyik (1987) referred to as West dialects is actually the dialects spoken in former Aceh Barat and Aceh Selatan districts. However, the two districts have now been expanded into eight independent districts. Former Aceh Barat district is now divided into four districts, Ace Jaya, Aceh Barat, Nagan Raya, and Simeuleu while Aceh Selatan is expanded into four districts, Aceh Barat Daya, Aceh Selatan, 
Subulussalam and Aceh Tamiang (Masykar, 2019; Masykar \& Nurrahmi, 2020). While some people in Aceh Selatan and Aceh Barat Daya speak Acehnese, they also speak another local language called Jamee. People in these areas may have acquired Acehnese due to constant contact with Acehnese near the border of Aceh Barat Daya and Nagan Raya. Each district has its distinct dialects.

Demographically, only people in Aceh Jaya, Aceh Barat, and Nagan Raya speak only Acehnese as their local language. If one were to come to Aceh Jaya, Aceh Barat, and Nagan Raya, they would find obvious differences in their dialects. People in parts of Aceh Jaya (Lamno, Calang, and Tenom) and parts of Aceh Barat (Samatiga, Kuala Bhee, Pante Cermen) tend to produce diphthong in open syllable words such as which is different from the study reported by Asyik (1987) and. Durie (1985) also mentioned that modern Acehnese tend to diminish diphthong in some words except among older people. If it is true, people in Aceh Barat may still retain diphthongs at the end of some Acehnese words when other dialects have evolved into monophthong.

Historically, Aceh Barat was part of the great Acehnese Kingdom, Kerajaan Nanggroe Aceh Darussalam. The kingdom might have spread the language to this region, or people from adjacent areas might migrate to this area. There are currently two routes connecting West Aceh with other Acehnese-speaking regions, the trans-regional road through Geurute mountains and the old Acehnese kingdom road through Aneuk Manyak mountains. Acehnese may take these routes to inhabit West Aceh long before the Dutch set their foot. West dialects may also be influenced by the Jamee language. It is the language of Acehnese descendants who migrated to Aceh from Minagkabau. The language is still used by the people in Aceh Barat who lived in Peunaga Rayeuk. In fact, the two famous national heroes, Teuku Umar and Cut Nyak Dhien, who fought against the Dutch actually the descendants of Minangkabau travelers who sailed to Aceh Barat (Kemendikbud, 2020; Raditya, 2019; Zainuddin, 1961). Thus, West Aceh dialects are unique in their influence from various other Acehnese dialects and the Jamee language. Al-Harbi (2003) reported that the Acehnese vowel of Pidie dialects has back vowel $/ \Lambda$ / closer to / / compared to the North dialects in Asyik (1987) and Durie (1985). Yusuf and Pillai (2016) also found that Acehnese people living in Kampung Keudah, Malaysia retains most of the vowels in their Acehnese despite the loss in $/ \Lambda /, / \partial /$, and in some cases /a/. They suggest lack of contact with Acehnese in Indonesia may contribute to some loss in vowels.

\section{Acehnese vowel inventories}

Previous studies on Acehnese vowels has been based on the North dialects (Abdullah et al., 2010; Asyik, 1987; Durie, 1985; Pillai \& Yusuf, 2012; Sulaiman et al., 1977). Studies of Acehnese on other dialects have been conducted by $\mathrm{Al}-$ Harbi (2003) on Pidie dialects and Aziz (2015) on West dialects. However, the focus of Aziz was more about the sociolinguistics aspect of the language instead 
of on the phonological aspect. The most comprehensive and recent studies on Acehnese vowels were made by Pillai and Yusuf (2012), Yusuf and Pillai (2013), and Yusuf and Pillai (2016).

Acehnese has been reported to contain ten oral vowels and seven nasal vowels (Asyik, 1987; Yusuf \& Pillai, 2013). Both oral and nasal vowels have their monophthongs dan diphthongs. However, not all diphthong reported by Asyik (1987) could be reproduced as expected in Yusuf's (2013) study. The 10 Acehnese oral monophthongs can be observed in Figure 1.

\begin{tabular}{|c|c|c|c|}
\hline High & /i/ & $/ \mathrm{dul} /$ & hu \\
\hline High-mid & lel & $\mid a /$ & lol \\
\hline Low-mid & $|\varepsilon|$ & $/ N$ & bo \\
\hline Low & & $/ a /$ & \\
\hline
\end{tabular}

Figure 1. Acehnese oral monophthong

The Acehnese oral vowels consist of three front vowels (/i/, /e/, and / $/$ /), four central vowels $(/ \mathrm{w} /, / \partial /, / \Lambda /$, and $/ \mathrm{a} /)$ and three back vowels $(/ \mathrm{u} /, / \mathrm{o} /$, and $/ \mathrm{s} /$ ). The front vowel $/ \mathrm{i} /$ is closed vowel while /e/ is near-closed vowel. The front vowel $/ \varepsilon /$ is a near-open vowel. The central vowels/w/ and /ə/are open and near-open vowels, while the vowel $/ \Lambda /$ and $/ \mathrm{a} /$ are near-close and close vowels, respectively. The back vowel $/ \mathrm{u}$ / is an unrounded close vowel. The vowel back vowels /o/ and /o/ are rounded near-close vowel and unrounded nearopen vowel, respectively. The distribution of English oral vowels are presented in the following table adapted from Asyik's (1987).

In addition to oral vowels, Acehnese also has seven nasal vowels. All oral vowels except /e/ / / / and /o/ have their nasal counterparts in Acehnese. They are front nasal vowel $(/ \tilde{\mathrm{i}} /$ and $/ \tilde{\varepsilon} /)$ central nasal vowel $(/ \tilde{\mathrm{u}} /, / \tilde{\Lambda} /$, and $/ \tilde{a} /)$ and back nasal vowel $(/ \tilde{u} /$ and $/ \tilde{\jmath} /)$. The nasal vowels can be observed in the following Figure:

\begin{tabular}{|c|c|c|c|}
\hline High & id & $/ \mathrm{un} /$ & $/ \mathrm{u} /$ \\
\hline High-mid & $|c|$ & $/ N$ & $/ \sigma$ \\
\hline Low-mid & & $/ \tilde{a} /$ & \\
\hline Low & & & \\
\hline
\end{tabular}

Figure 2. Acehnese nasal monophthongs 
In term of diphthong, Acehnese has 10 diphthongs ending with / / / and 7 diphthongs ending with / i/ (Nucifera, 2018; Yusuf \& Pillai, 2013). Diphthongs

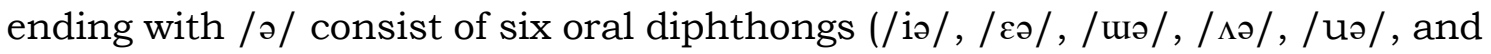

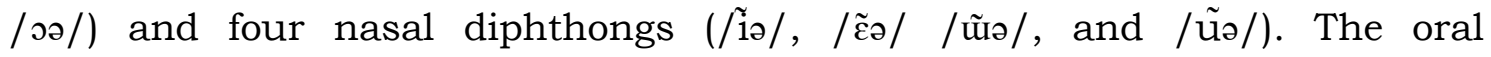
diphthongs end with /i/ are /əi/, / $\Lambda$ /, / ui/, /oi/ and / $\mathrm{i} /$ and / ai/ while the

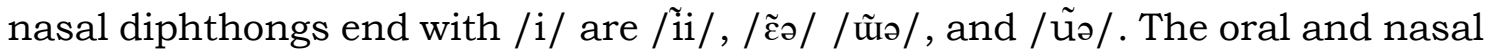
diphthongs can be observed in the Figure 3.

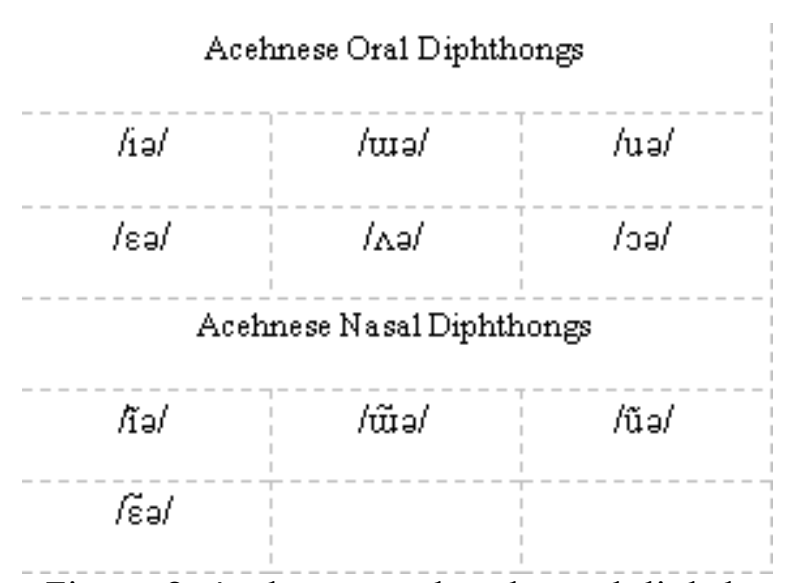

Figure 3. Acehnese oral and nasal diphthongs

\section{METHOD}

The participants in this study were 3 Acehnese male speakers speaking only Acehnese as their local language and spent most of their livelihood in Aceh Barat. It is common for phonetic studies to involve only a few people (Low, 2016). Prior to selection, proficiency questionnaires were asked about the number of languages they are fluent in and which language they often use in various daily settings. Only Acehnese aged 35-50 years old participated in this study because their dialects are more uniform than youth. The participants were selected by the convenient sampling method. A consent form was distributed and signed by the participants prior to data collection.

\section{Data collection}

Participants produce a set of Acehnese words, and their utterances were recorded into a high-quality Zoom $\mathrm{H} 1$ recorder in a quiet room. A rode lavalier mic was clipped into their clothes to ensure consistent quality of the recording. The words were presented in pictures with Indonesian translation included in the picture instead of reading the written sentences. Burgos et al. (2014) found that orthography might encourage respondents to produce the words as written and deviate the obtained data from the original objective, actual production of target vowels. Thus, We adapt the task used by Bongaerts et al. (1997) in which 
participants produce speech based on the represented pictures. The wordlists and pictures were adapted from Pillai and Yusuf (2012).

To collect the data, a research assistant asked the speakers in Acehnese, 'Gamba nyo peu lam Bahasa Aceh?' [What is this in Acehnese?] with the picture presented in front of them. The participants replied by answering in the control sentence, 'Nyoe lam Bahasa Aceh ...' [It is in Acehnese ...]. They articulated the lists three times with a pause in between recordings. If they made mistakes, that the word they used to refer to the picture was not what we targeted, further elaboration was made in Indonesian without telling them what the Acehnese word is. This only happens if they utter other Acehnese words that the researchers have not intended given the picture presented. The words used to attain the target phonemes can be observed in Table 1 .

Table 1. Acehnese words used to obtain target phoneme

\begin{tabular}{ccc}
\hline Acehnese Words & Target Phoneme & English Translation \\
\hline cit & $\mathbf{i}$ & too, also \\
pét & $\mathbf{e}$ & close eyes \\
cèt & $\boldsymbol{\varepsilon}$ & paint \\
peut & $\mathbf{u}$ & four \\
tet & $\mathbf{o}$ & burn \\
göt & $\mathbf{a}$ & good \\
pat & $\mathbf{a}$ & where \\
& & title for Acehense \\
cut & $\mathbf{u}$ & noble women \\
pott & $\mathbf{o}$ & blow \\
cok & $\mathbf{o}$ & take \\
\hline
\end{tabular}

\section{Data analysis}

The data were analyzed using Praat Software Version 6.1 .29 (Boesarma \& Weenink, 2020). Each sound file is loaded into the software and labeled with targeted Acehnese words and phonetic symbols. The author manually selected the start and endpoint of the target phoneme in the linear predictive coding. The Formant 1 (F1) and Formant 2 (F2) are automatically generated using a Praat script producing a start, mid and endpoint values for each F1 and F2 in Hertz $(\mathrm{Hz})$. The script automatically read the labeled words and phonetic symbol made in the linear predictive coding. Only the midpoint frequencies are taken to determine the height (F1) and the depth (F2) of each vowel (Hayward, 2013). The Hertz values of each F1 and F2 are converted into Bark using the formulas suggested by Zwicker and Terhardt (1980, p. 1524) and Deterding (2003). The data analysis process through the Praat software can be observed in Figure 4. 


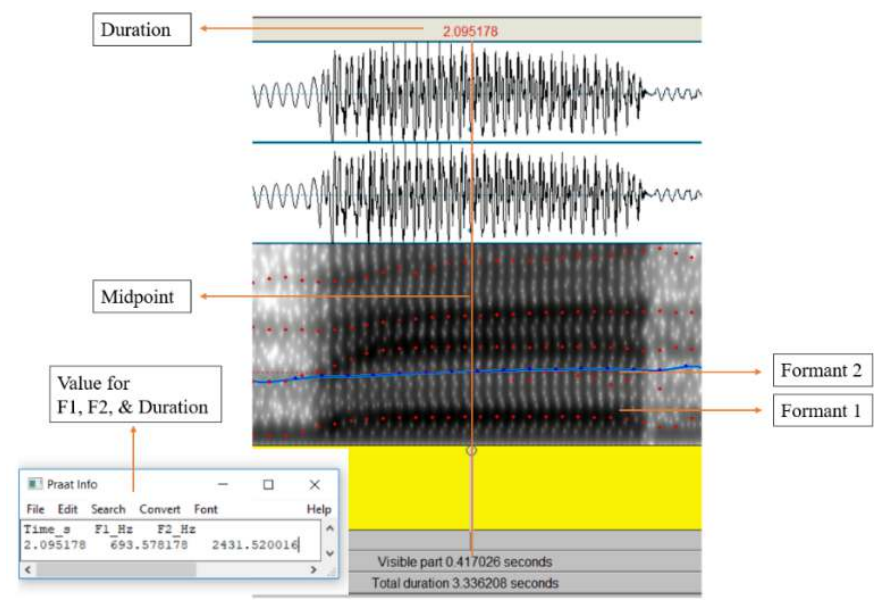

Figure 4. Example of formant measurements

\section{RESULTS AND DISCUSSION}

The average formant frequencies for each targeted phoneme of Acehnese vowel monthlong are presented in Table 2. The values are presented in Hertz and Bark scale. The formant plot for the targeted phonemes of Acehnese oral monophthongs is presented in Figure 5. The vowel space of the Aceh Barat dialect in Table 2 for $\mathrm{F} 1$ is between $370 \mathrm{~Hz}$ and $750 \mathrm{~Hz}$, while for the F2 is from $920 \mathrm{~Hz}$ to $2080 \mathrm{~Hz}$. The front vowel /i/ is produced close to the high front vowel /e/ while the low front vowel $/ \varepsilon /$ is produced further down the vowel space. The / $\mathrm{i} /$ vowel is the most front in Aceh Barat Dialect. The four mid Acehnese vowels in Figure $5 / \mathrm{w} /, / \partial /, / \Lambda /$, and $/ \mathrm{a} /$ are produced variably. The vowels $/ \mathrm{w} /, / \Lambda /$, and /a/ are positioned equally apart from each other while the /ə/ vowel is positioned closer to the back vowel / $\mathrm{u}$ / than to any other three mid vowels. The vowel /a/ is the lowest vowel in the Aceh Barat dialect. The three back-vowel $/ \mathrm{u} /, / \mathrm{o} /$, and $/ \mathrm{o} /$ are positioned equally further apart from each other. The vowel /o/ is the furthest back vowel, and the unrounded back vowel / / is positioned lower than the vowel $/ \mathrm{u} /$ and $/ \mathrm{o} /$.

Table 2. Formant values of Acehnese monophthongs in Hertz (Hz) and Bark

\begin{tabular}{ccccc}
\hline & F1 (Hz) & F2 (Hz) & F1 (Bark) & F2 (Bark) \\
\hline $\mathrm{i}$ & 385 & 2077 & 3.71 & 13.35 \\
$\mathrm{e}$ & 416 & 2012 & 3.99 & 13.14 \\
$\varepsilon$ & 523 & 1885 & 4.94 & 12.72 \\
$\mathrm{u}$ & 372 & 1381 & 3.59 & 10.64 \\
$\partial$ & 430 & 1221 & 4.12 & 9.82 \\
$\Lambda$ & 532 & 1413 & 5.01 & 10.80 \\
$\mathrm{a}$ & 745 & 1312 & 6.73 & 10.30 \\
$\mathrm{u}$ & 373 & 1140 & 3.60 & 9.36 \\
$\mathrm{o}$ & 433 & 926 & 4.14 & 8.03 \\
$\mathrm{o}$ & 533 & 1182 & 5.02 & 9.60 \\
\hline
\end{tabular}


Masykar, T., Agusmaniza, R., Masykar, N. T., \& Nurrahmi, F. (2021). An instrumental analysis of oral monophthongs in Aceh Barat dialect of Acehnese. EduLite: Journal of English Education, Literature, and Culture, 6 (2), 383-396. http://dx.doi.org/10.30659/e.6.2.383-396

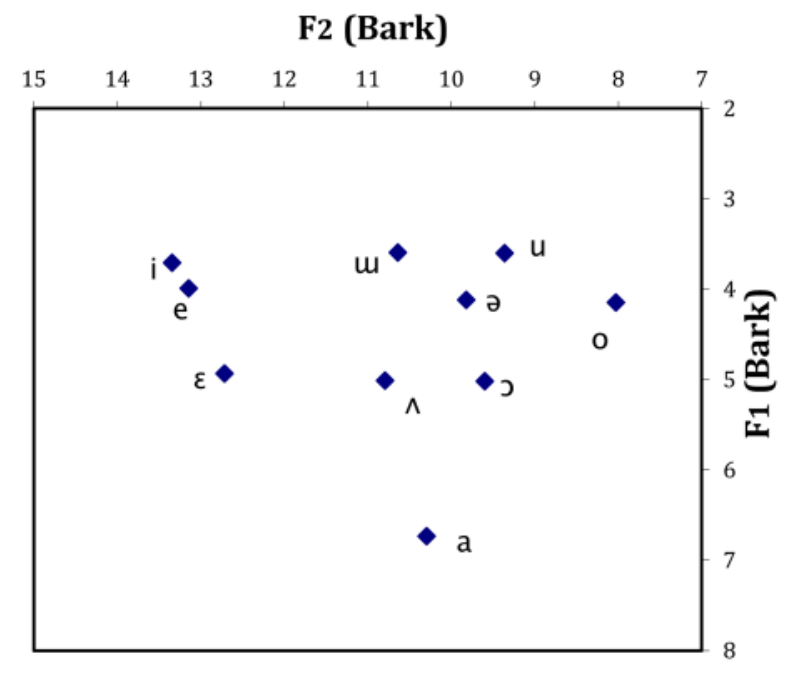

Figure 5. Oral monophthong vowel plots of Aceh Barat Dialect

\section{The front vowel $/ \mathrm{i} /, / \mathrm{e} /$, and $/ \varepsilon /$}

The scatter plot of the Aceh Barat dialect of Acehnese front monophthongs is presented in Figure 6. A total of 27 tokens of front vowels were extracted from the recorded data comprising of 9 tokens within each phoneme produced by three speakers. All the three front vowels are produced between $320 \mathrm{~Hz}$ and 580 $\mathrm{Hz}$ for $\mathrm{F} 1$ and from $1700 \mathrm{~Hz}$ to $2200 \mathrm{~Hz}$ for F2. The /i/ vowel is the most front vowel followed by $/ e /$ and $/ \varepsilon /$. It is evident that all three speakers maintain the distinction between the three front vowels even though their average production of the vowels/i/ and /e/ is located close together in Figure 5.

The lowest $\mathrm{F} 1$ for the phoneme / $\mathrm{i}$ / is $325 \mathrm{~Hz}$, while the highest is $385 \mathrm{~Hz}$. As for the F2 frequencies, it spans from $1970 \mathrm{~Hz}$ to $2200 \mathrm{~Hz}$. The phoneme /e/ has the formant frequencies between $380 \mathrm{~Hz}$ and $450 \mathrm{~Hz}$ for $\mathrm{F} 1$ and between $1910 \mathrm{~Hz}$ and $2150 \mathrm{~Hz}$ for $\mathrm{F} 2$. The $\mathrm{F} 1$ frequencies for the phone / $\varepsilon /$ are from 500 $\mathrm{Hz}$ to $570 \mathrm{~Hz}$, while for $\mathrm{F} 2$ are from $1730 \mathrm{~Hz}$ to $2000 \mathrm{~Hz}$. Clearly, the production of / $\mathrm{i} /$ and /e/ is mapped among West Acehnese speakers. The lowest F1 values for the phoneme /e/ is actually in the highest F1 values for the phoneme /i/.

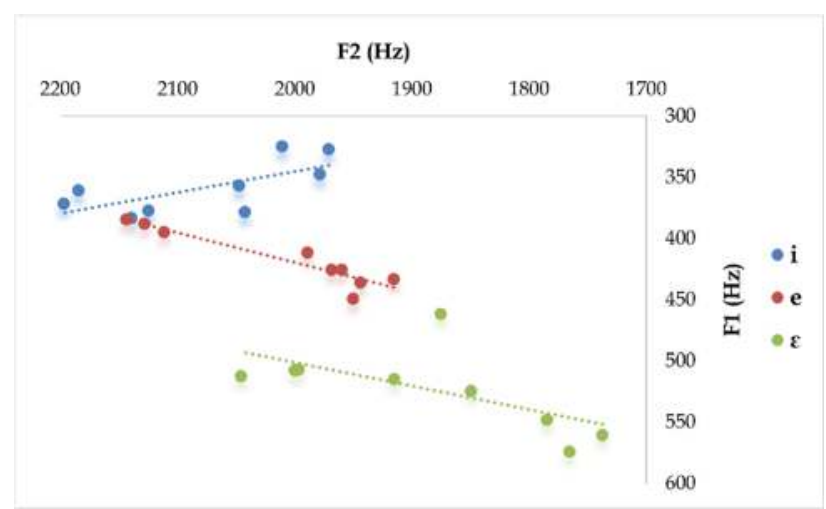

Figure 6. Scatter plot of front vowel formant frequencies 


\section{The mid vowel $/ \mathrm{u} /, / \partial /, / \Lambda /$, and $/ \mathrm{a} /$}

The scatter plot for the Acehnese mid monophthong vowels of the Aceh Barat dialect can be observed in Figure 7 . The three speakers produced 36 tokens of mid vowels with nine tokens for each target phoneme. The formant frequencies for all mid vowels are between $320 \mathrm{~Hz}$ and $720 \mathrm{~Hz}$ for $\mathrm{F} 1$ and between $950 \mathrm{~Hz}$ and $1900 \mathrm{~Hz}$ for F2. All speakers maintain the distinction between the four mid vowels without any single token overlapped into another. However, it is apparent that some of the F2 frequencies for each vowel stretch considerably across the vowel space.

The phoneme / $\mathrm{w} /$ is the highest mid vowel in the category. Its F1 frequencies are between $320 \mathrm{~Hz}$ and $390 \mathrm{~Hz}$, while its $\mathrm{F} 2$ frequencies span between $1250 \mathrm{~Hz}$ and $1600 \mathrm{~Hz}$. The / //vowel is produced closed to / w/ but is not overlapped as /i/ and /e/in Figure 6. The F1 frequencies for the phoneme /ə/are from $420 \mathrm{~Hz}$ to $460 \mathrm{~Hz}$, while its F2 frequencies are from $950 \mathrm{~Hz}$ to 1500 $\mathrm{Hz}$. The $/ \Lambda /$ and $/ \mathrm{a} /$ are both placed in the lower space of the mid vowel category. Some of the tokens for both phonemes are located further from the Y-axis. The former has $\mathrm{F} 1$ frequencies stretching from $500 \mathrm{~Hz}$ and to $560 \mathrm{~Hz}$ and $\mathrm{F} 2$ frequencies from $1100 \mathrm{~Hz}$ to $1900 \mathrm{~Hz}$. The latter has the $\mathrm{F} 1$ frequencies from $690 \mathrm{~Hz}$ to $800 \mathrm{~Hz}$ and F2 frequencies from $980 \mathrm{~Hz}$ to $1470 \mathrm{~Hz}$.

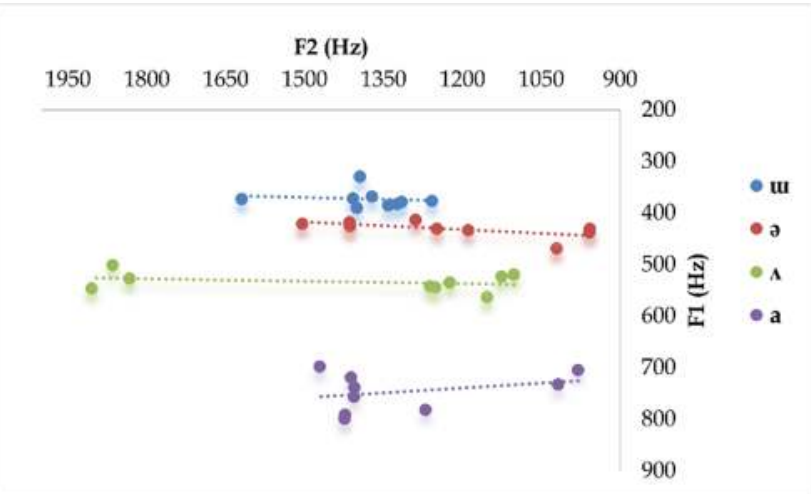

Figure 7. Scatter plot of mid vowel formant frequencies

\section{The Back Vowel /u/, /o/, and /o/}

Figure 8 shows the scatter plot of the Aceh Barat dialect of Acehnese back vowel. Each speaker produced three tokens of each back vowel generating a total of 27 tokens of back vowels. The three back vowels are located equally distant from each other, indicating a clear distinction among the back vowels. No tokens of back vowels overlapped into one another but the F2 frequencies for the phoneme $\mathrm{lu} /$ and $/ \mathrm{o} /$ stretch further apart compared to the phoneme /o/. The F1 frequency ranges for $/ \mathrm{u} / \mathrm{\rho} /$ and /o/ are $350-400 \mathrm{~Hz}, 410-450 \mathrm{~Hz}, 465-570 \mathrm{~Hz}$, respectively while the F2 frequencies are 925-1050 Hz 845-1035 Hz 980-1280 $\mathrm{Hz}$ accordingly. 
However, when all tokens of vowels are placed into the scatter plot as in Figure 9, some speakers produced certain monophthongs overlapping with one another. It is evident that some tokens of the mid vowel / w/ intersects with the back vowel $/ u /$ while some of the tokens for the vowel $/ \Lambda /$ conflate to the vowel $/ \varepsilon /$ in the higher F2 frequencies and to the vowel $\rho$ to the lower F2 frequencies. Aceh Barat speakers also produce some tokens of vowel a within range rounded back vowel /o/. Obviously, variation exists within the speakers of Aceh Barat dialects, especially within the high back and high front vowel categories.

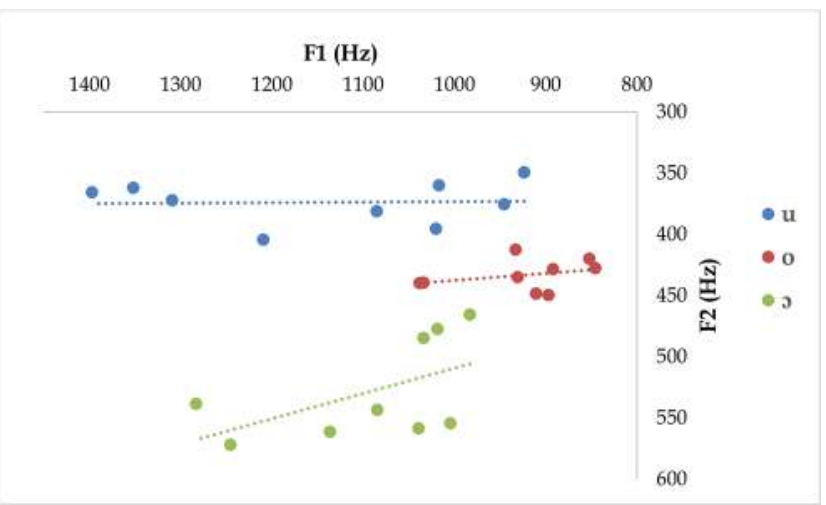

Figure 8. Scatter plot of back vowel formant frequencies

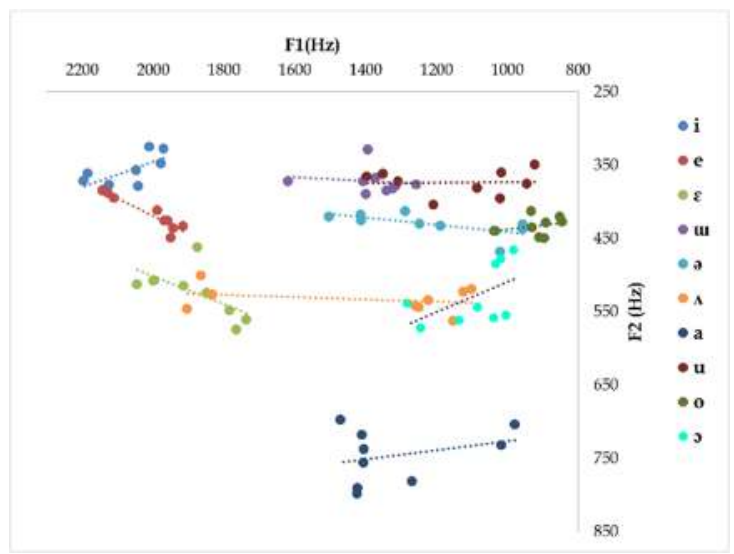

Figure 9. Scatter plot of back vowel formant frequencies

\section{Discussion}

It is evident from the current study that West Aceh speakers maintain most of the vowels similar to the Pase dialect of Acehnese in the previous study (Asyik, 1987; Durie, 1985; Pillai \& Yusuf, 2012). However, some vowels, especially back and mid vowel in the West Aceh dialect of Acehnese, is somewhat different from the Pase dialect described by Pillai and Yusuf (2012). When the vowels are grouped into the front, mid and back categories following Asyik (1987), Aceh Barat speakers produce each vowel within the categories distinctly from one another. Conversely, when each speakers' tokens of all vowels were plotted against the other, some overlapping exist across categories. Some mid vowels 
intersect with back and front vowel, especially the vowel $/ \Lambda /, / \curvearrowright /, / 0 /, / \curvearrowright /$ and $/ \varepsilon /$.

This overlapping phenomenon suggests that some speakers might produce certain vowels as other vowels, as found in the study by Yusuf and Pillai (2016) in the Keudah variety of Acehnese in Malaysia. Deterding et al. (2008) also found a similar pattern in which some English phonemes are produced as other phonemes by Hongkong speakers of English. The current findings further support the claims made by Durie (1985) that variation along the West coast of Aceh is much greater than the northern part of Aceh. It is different to the point that some Achenese speakers might find challenging to understand. However, to confirm such variation, further inquiry should be made through a native speaker judgment test as suggested by Jiang (2018) to see if the overlapped vowels are indeed produced as other vowels.

Aceh Barat's vowel / $/$ / is more back and located further from the mid vowel /ə/ in Yusuf and Pillai's (2012) study. One explanation for this is that some Aceh Barat speakers might produce /ə/vowels as the back vowel. It is evident that the F2 frequencies of each speaker for the vowel /o/vary considerably. Another notable feature of the Aceh Barat dialect is the location of the vowel $/ \Lambda /$, which is in close proximity to the back unrounded vowel $/ \mathrm{\rho} /$. Individual analysis in Figure 9 indicates that some speakers produce the vowel $/ \Lambda /$ within the vowel space $/ \supset /$ and $/ \varepsilon /$. A similar pattern was also found in the Keudah variety of Acehnese in Malaysia (Yusuf \& Pillai, 2013) in which the vowel $/ \Lambda /$ is produced as either $/ \rho /$ and $/ \varepsilon /$. Another possible explanation is that some West Aceh speakers might produce the target words differently from those produced by the Pase speakers. To confirm this, future studies should use other words that might target the phoneme $/ \Lambda /$. If the Keudah variety of Acehnese in Malaysia produces the vowel $/ \Lambda /$ as the vowel $/ \rho /$ and $/ \varepsilon /$, it is suspected that the West Aceh dialect is closer to Keudah variety compared to the Pase variety.

Alternative explanation for individual variation for the vowel $/ \Lambda /, / \curvearrowright /, / 0 /$, $/ \rho /$ and $/ \varepsilon /$ is that variations exist even within Aceh Barat dialect. They may produce certain words as a phoneme different from those produced by other Acehnese speakers. Aceh Barat speakers might produce $/ \Lambda /$ as $/ \rho /$ or $/ \varepsilon /$ depending on the words where it resides, or any words produced as $/ \Lambda /$ by other the north Aceh speakers are actually produced as $/ \supset /$ and $/ \varepsilon /$ by Aceh Barat speakers. The word used in the current study to target the phoneme $/ \Lambda /$ is göt /gnt/ [good]. Future study should try to target the phoneme using other words that might contains $/ \Lambda /$ such as poit /p $\Lambda$ t/ [pick], seutot / sut $\Lambda$ t/ [follow], and peugot / pugst/ [fix]. A similar explanation should accommodate the overlapping of some tokens of the vowel /o/into /o/. Words that might target the phoneme /o/ in Aceh Barat dialect include ret/rət/[fall], cet/cət/[picking fruits using a wooden pole], and bet /bot/[uprooting plant] 


\section{CONCLUSION}

In general, the current study lends its support to Asyik (1987), Durie (1985), and Pillai and Yusuf (2012) studies on the Pase dialect of Acehnese. However, some differences emerge in this study, especially for the mid vowel $/ \Lambda /$ and $/ \curvearrowright /$, even though different ways of pronunciation of certain words might contribute to such differences. Some Aceh Barat speakers produce the word that contains the vowel $/ \Lambda /$ as closer to $/ \rho /$ and $/ \varepsilon /$. Such deviation seems to resemble the vowel production by Keudah variety of Acehnese in Yusuf and Pillai's (2013) study. Some speakers also produce the vowel /o/ closer to the back vowel /o/. This variation indicates that the Aceh Barat dialect exhibits varieties in the way certain mid vowels are produced.

While it is suspected that some mid vowels produced by Aceh Barat speakers deviate from the Pase variety, it is possible that the difference is wordspecific due to different pronunciations. Future studies should use different words to confirm this assumption. Dialect in Aceh Barat has been mentioned to vary greatly (Durie, 1985), and it is possible that certain words might be produced differently from other Acehnese speakers. The people from Samatiga, for example, tend to produce the word-final monophthongs as diphthongs while other people in Aceh Barat produce them as monophthong. The consonant / r/ has also been used as an indication of identity to recognize the Aceh Barat people or the use of liquid / $/$ as opposed to / $\mathrm{r} /$ among some people in Blang Pidie. Since there have not been any instrumental analysis studies on dialects along the west coast of Aceh, this study should set as the benchmark for further rigorous studies on dialects in this part of Aceh.

\section{ACKNOWLEDGEMENTS}

This study is funded by the Ministry of Education, Culture, Research and Technology through Novice Lecturer Research Scheme (PDP) of 2020.

\section{REFERENCES}

Abdullah, W., Abdullah, F. S. i., Faridah, H. B., \& Husni, T. (2010). Peulajaran Basa Aceh Keu Murip Glah VIII SMP/MTs [Acehnese Language Textbook for Public/Religious Junior High School Students Grade 8]. Global Educational Consultant Institute.

Al-Harbi, A. A. A.-A. (2003). Acehnese coda condition: An optimality-theoretic account. Umm Al-Qura University Journal of Educational and Social Sciences and Humanities, 15(1), 9-28. http://roa.rutgers.edu/article/view/604

Asyik, A. G. (1987). A contextual grammar of Acehnese. Ann Arbor: University of Michigan dissertation. ProQuest Dissertations and Theses Global.

Aziz, Z. (2015). A sociolinguistic investigation of Acehnese with a focus on West Acehnese: a stigmatised dialect. http://hdl.handle.net/2440/92352 
Boesarma, P., \& Weenink, D. (2020). PRAAT: Doing Phonetics by Computer. In http://www.praat.org/

Bongaerts, T., van Summeren, C., Planken, B., \& Schils, E. (1997). Age and ultimate attainment in the pronunciation of a foreign language. Studies in second language acquisition, 447-465. https://www.jstor.org/stable/44487989

Burgos, P., Cucchiarini, C., van Hout, R., \& Strik, H. (2014). Phonology acquisition in Spanish learners of Dutch: Error patterns in pronunciation. Language Sciences, 41, 129-142. https://doi.org/10.1016/j.langsci.2013.08.015

Deterding, D. (2003). An instrumental study of the monophthong vowels of Singapore English. English World-Wide, 24(1), 1-16. https://doi.org/10.1075/eww.24.1.02det

Deterding, D., Wong, J., \& Kirkpatrick, A. (2008). The pronunciation of Hong Kong English. English World-Wide, 29(2), 148-175. https://doi.org/10.1075/eww.29.2.03det

Durie, M. (1985). A grammar of Acehnese on the basis of a dialect of North Aceh. Foris Publications.

Hayward, K. (2013). Experimental phonetics. Routledge. https://doi.org/10.4324/9781315842059

Jiang, N. (2018). Second Language Processing: An Introduction. Routledge.

Kemendikbud. (2020). Sejarah singkat Teuku Umar Pahlawan Nasional dari Aceh. https://kebudayaan.kemdikbud.go.id/bpcbaceh/sejarah-singkat-teuku-umaryang-di-gelar-sebagai-johan-pahlawan/

Low, E.-L. (2016). Phonological patterning for English as a lingua franca in Asia: Implications for norms and practice in multilingual Asia. Journal of English as a Lingua Franca, 5(2), 309-332. https://doi.org/10.1515/jelf-2016-0022

Masykar, T. (2019). Analisa kebutuhan English for specific purpose untuk pendidikan vokasi. VOCATECH: Vocational Education and Technology Journal, 1(1), 47-50. https://doi.org/10.38038/vocatech.v1i0.9

Masykar, T., \& Nurrahmi, F. (2020). Motivation and satisfaction towards two-year vocational diploma. Jurnal Pendidikan Vokasi, 10(1), 10-21. https://doi.org/10.21831/jpv.v10i1.30123

Nucifera, P. (2018). Diftong dalam Bahasa Aceh Penelitian pada Masyarakat Penutur Asli Bahasa Aceh di Desa Meunasah Reudeup Kabupaten Bireun, Aceh. Jurnal Samudra Bahasa, 1(1), https://www.ejurnalunsam.id/index.php/JSB/article/view/977

Pillai, S., \& Yusuf, Y. Q. (2012). An instrumental analysis of Acehnese oral vowels. Language and Linguistics, 13, 1029-1050. https://www.proquest.com/docview/1525426105?pqorigsite $=$ gscholar\&fromopenview $=$ true

Raditya, I. N. (2019). Sejarah 11 Februari 1899: Kronik Gugurnya Teuku Umar. https://tirto.id/sejarah-11-februari-1899-kronik-gugurnya-teuku-umar-dgFF

Sulaiman, B., Jusuf, H., Hanum, S., Lani, R. C., \& Ali, Z. (1977). Struktur Bahasa Aceh (Lanjutan)[Acehnese Structure (Advanced)]. Banda Aceh: Depdikbud.

Yusuf, Q., \& Pillai, S. (2013). An acoustic description of diphthongs in two varieties of acehnese. Pertanika Journal of Social Science and Humanities, 21, 153-158. 
Masykar, T., Agusmaniza, R., Masykar, N. T., \& Nurrahmi, F. (2021). An instrumental analysis of oral monophthongs in Aceh Barat dialect of Acehnese. EduLite: Journal of English Education, Literature, and Culture, 6 (2), 383-396. http://dx.doi.org/10.30659/e.6.2.383-396

http://www.pertanika.upm.edu.my/pjssh/browse/special-issue?article=JSSH$\underline{0732-2012}$

Yusuf, Y. Q., \& Pillai, S. (2016). An instrumental study of oral vowels in the Kedah variety of Acehnese. Language Sciences, 54, 14-25. https://doi.org/10.1016/j.langsci.2015.09.001

Zainuddin, H. (1961). Tarich Atjeh dan Nusantara (Vol. 1). Pustaka Iskandar Muda.

Zwicker, E., \& Terhardt, E. (1980). Analytical expressions for critical-band rate and critical bandwidth as a function of frequency. The Journal of the Acoustical Society of America, 68(5), 1523-1525. https://doi.org/10.1121/1.385079

Conflict of Interest Statement: The authors declare that the research was conducted in the absence of any commercial or financial relationships that could be construed as a potential conflict of interest.

Copyright (C) 2021 Masykar, Agusmaniza, Masykar, and Nurrahmi. This is an open-access article distributed under the terms of the Creative Commons Attribution License (CC BY). The use, distribution or reproduction in other forums is permitted, provided the original author(s) and the copyright owner(s) are credited and that the original publication in this journal is cited, in accordance with accepted academic practice. No use, distribution or reproduction is permitted which does not comply with these terms. 